Acta vet. scand. $1984,25,86-95$.

From the Department of Pharmacology and Toxicology, Royal Veterinary and Agricultural University, Copenhagen, Denmark.

\title{
OBIDOXIME REACTIVATION OF ORGANOPHOSPHATE-INHIBITED CHOLINESTERASE ACTIVITY IN PIGS
}

By

N. Gyrd-Hansen and I. Kraul

GYRD-HANSEN, N. and I. KRAUL: Obidoxime reactivation of organophosphate-inhibited cholinesterase activity in pigs. Acta vet. scand. $1984,25,86-95$. - The ability of obidoxime to reactivate organophosphate-inhibited cholinesterases was studied in pigs treated with either trichlorfon, dichlorvos or coumaphos. In 6 pigs cholinesterase activity was measured in the blood samples both before and after in vitro reactivation with obidoxime. Three pigs were treated with obidoxime $6 \mathrm{~h}$ after administration of the organophosphates in order to study the possibility of in vivo reactivation.

The results show a close correlation between the ability of obidoxime to reactivate the inhibited cholinesterases in vitro and in vivo. However, there was a marked difference in the possibility of reactivation between the 3 organophosphates. Thus no reactivation was possible after treatment with dichlorvos, while reactivation could be achieved for at least $6 \mathrm{~h}$ after administration of trichlorfon. After coumaphos treatment reactivation with obidoxime was possible for more than $24 \mathrm{~h}$.

obidoxime; trichlorfon; dichlorvos; coumaphos; cholinesterase activity; pigs.

In 1951 Wilson showed that acetylcholinesterase inhibited by an organophosphate, tetraethylpyrophosphate (TEPP), could be reactivated by means of hydroxylamine or choline. This discovery started the use of cholinesterase-reactivators in the treatment of organophosphate poisonings. Among these reactivators pralidoxime $^{1}$ (Wilson \& Ginsburg 1955) is probably the best known and has been proved efficient against poisoning with TEPP, di-isopropylfluorophosphate (DFP), paraoxon and parathion a.o. (vide Hobbiger 1957, Karlog 1960). Today pralidoxime has to a great extent been replaced by the more potent obidoxime ${ }^{2}$

1 Pyridine-2-aldoxime methiodide.

2 Bis (4-hydroxyimin omethyl-pyridinium-1-methyl) ether dichloride. 
(Heilbronn \& Tolagen 1965, Natoff \& Reiff 1970). Treatment with reactivators was soon shown to be less efficient when the enzyme inhibition had persisted for some time than in acute cases (Hobbiger 1956, 1957, Davies \& Green 1956). Furthermore the therapeutic value of the reactivators was found to vary considerably according to chemical structure and enzyme-phosphorylating properties of the organophosphates (Sanderson \& Edson 1959).

In Denmark 3 organophosphates are being used in veterinary practice - trichlorfon for the treatment of ecto- and endoparasites, dichlorvos for endoparasites and coumaphos for ectoparasites. In high roses they all produce cholinesterase inhibition and it is the purpose of the present study to examine the reactivating capacity of obidoxime on the cholinesterase activity in blood from pigs treated with these 3 organophosphates.

\section{MATERIALS AND METHODS}

Nine pigs of the Danish Landrace breed with a body weight between 18 and $28 \mathrm{~kg}$ were used for this study. The pigs were kept separately with free access to water and were fed a commercial mixture twice daily according to weight.

The following 3 organophosphates were administered orally to the pigs: Trichlorfon (Neguvon ${ }^{\circledR}$ vet.), dichlorvos (Atgard $\AA$ vet.) and coumaphosa (Fig. 1). Trichlorfon and coumaphos were

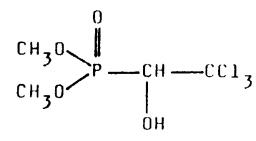

TR I CHLORF ON (METRIFONATUH NFN)

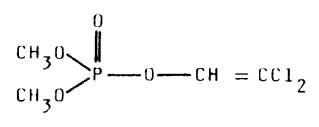

DICHLORVOS

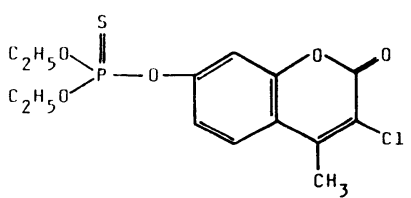

COUMAPHOS
F i gur e 1. Chemical structures of the drugs used. 
given as the pure chemical while Atgard $\circledast$ vet. is a sustained release preparation where dichlorvos is incorporated into polyvinyl chloride pellets. The treatment of the individual pigs as well as the dosages used are given in Table 1. The organophosphates were administered in the feed and were mixed in one third of the normal ration, which was given before the remaining two thirds, in order to ensure complete consumption of the drugs.

In pigs nos. 3, 6 and 9 a cholinesterase reactivator obidoxime (Toxogonin $®)^{b}$ was administered intravenously $6 \mathrm{~h}$ after the pigs had been given the organophosphate-containing feed (Table 1).

T a b l e 1. Dosages of organophosphates and obidoxime administered to 9 pigs.

\begin{tabular}{clcc}
\hline Pig no. & Organophosphate & $\begin{array}{c}\text { Dosage } \\
(\mathrm{mg} / \mathrm{kg})\end{array}$ & $\begin{array}{c}\text { Obidoxime } \\
(\mathrm{mg} / \mathrm{kg})\end{array}$ \\
\hline 1 and 2 & Trichlorfon & $100^{\star}$ & 0 \\
3 & Trichlorfon & $100^{\star}$ & 10 \\
4 and 5 & Dichlorvos & $100^{\star}$ & 0 \\
6 & Dichlorvos & $100^{\star}$ & 10 \\
7 and 8 & Coumaphos & 25 & 0 \\
9 & Coumaphos & 25 & 10 \\
\hline
\end{tabular}

* $100 \mathrm{mg} / \mathrm{kg}$ is twice the recommended dose.

Blood samples were taken before administration of the organophosphates and $0.5,1,2,4,6,24,30,48,72,96,168$ and $240 \mathrm{~h}$ after. In those pigs, which were treated with obidoxime additional blood samples were collected $0.5,1,2,4$ and $6 \mathrm{~h}$ after the injection of obidoxime. Heparin was used as anticoagulant.

Cholinesterase activity was measured in whole blood as well as in plasma by the manometric Warburg-technique described by Augustinsson (1948). Cholinesterase activities are given as percentages of the activity in the control samples. In the samples from pigs nos. 1, 2, 4, 5, 7 and 8 cholinesterase activity was measured in whole blood both before and after in vitro cholinesterase reactivation was tried by incubation with $2 \cdot 10^{-3} \mathrm{~mol} / \mathrm{l}$ obidoxime (in Warburg buffer $\mathrm{pH} 7.6$ ) for $2 \mathrm{~h}$ at $20-22^{\circ} \mathrm{C}$.

b Kindly supplied by Nordisk Droge. 


\section{RESULTS}

None of the pigs were seriously affected by the treatment they received although pigs nos. 1 and 2 showed some excitation and muscle tremor 1-4 h after the administration of trichlorfon.

The effects of trichlorfon, dichlorvos and coumaphos on the cholinesterase activity in whole blood and plasma are illustrated in Figs. 2A, 3A and 4A, respectively. In all pigs the organophosphates caused a marked decrease in the cholinesterase activity in blood and especially in plasma. However, within the observation period of $\mathbf{1 0}$ days a spontaneous reactivation took place with the activity in plasma as well as whole blood returning almost to control values.

In the Figs. mentioned the activities in whole blood before and after in vitro reactivation with obidoxime can be compared. For trichorfon (Fig. 2A) the activity in the reactivated blood samples is twice as high as in the untreated samples during the first $4 \mathrm{~h}$, after which this difference decreases and has disappeared completely at $24 \mathrm{~h}$. With dichlorvos there is no real difference between the cholinesterase activities in the reactivated and the untreated blood samples at any time. Coumaphos on the other hand causes a cholinesterase inhibition, which can be reactivated in vitro during the first $30 \mathrm{~h}$. At $6 \mathrm{~h}$ the activity in the reactivated sample is nearly twice as high as in the untreated one and at $24 \mathrm{~h}$ the difference is still $50 \%$.

In order to examine the relationship between in vitro and in vivo reactivation of organophosphate-inhibited cholinesterases pigs nos. 3, 6 and 9 were treated with obidoxime $6 \mathrm{~h}$ after the organophosphate administration and the results are shown in Figs. 2B, 3B and 4B.

In the trichlorfon-treated pig (Fig. 2B) obidoxime is able to increase the cholinesterase activity from 25 to $40 \%$ of the control value, which corresponds well with the in vitro effect of obidoxime (Fig. 2A).

In vitro reactivation had little effect on the enzyme activity in blood samples from dichlorvos-treated pigs (Fig. 3A) and the same was the case when obidoxime was administered to the pig itself (Fig. 3B).

However, when the coumaphos-treated pig received obidoxime a $100 \%$ increase of the enzyme activity in the blood was observed within $1 / 2 \mathrm{~h}$, i.e. a rise in activity from 45 to $90 \%$ of the 

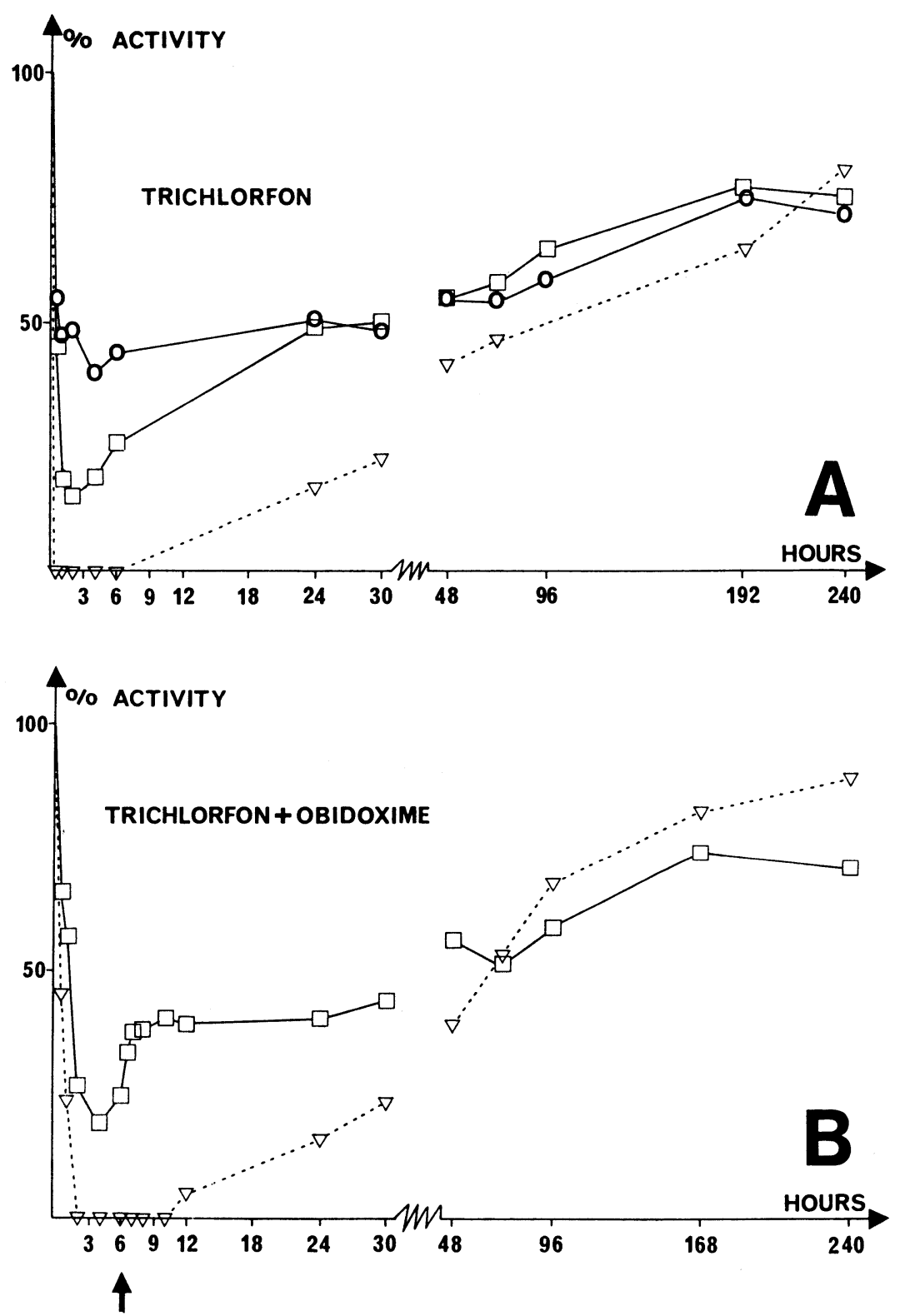

F i g u r e 2A \& B. Cholinesterase activity as per cent of control in plasma and whole blood from pigs nos. 1 (A) and 3 (B) both treated with trichlorfon. $(\nabla)$ plasma; $(\square)$ whole blood; (O) whole blood after in vitro reactivation with obidoxime $(A)$. The arrow indicates in vivo treatment with obidoxime (B). 

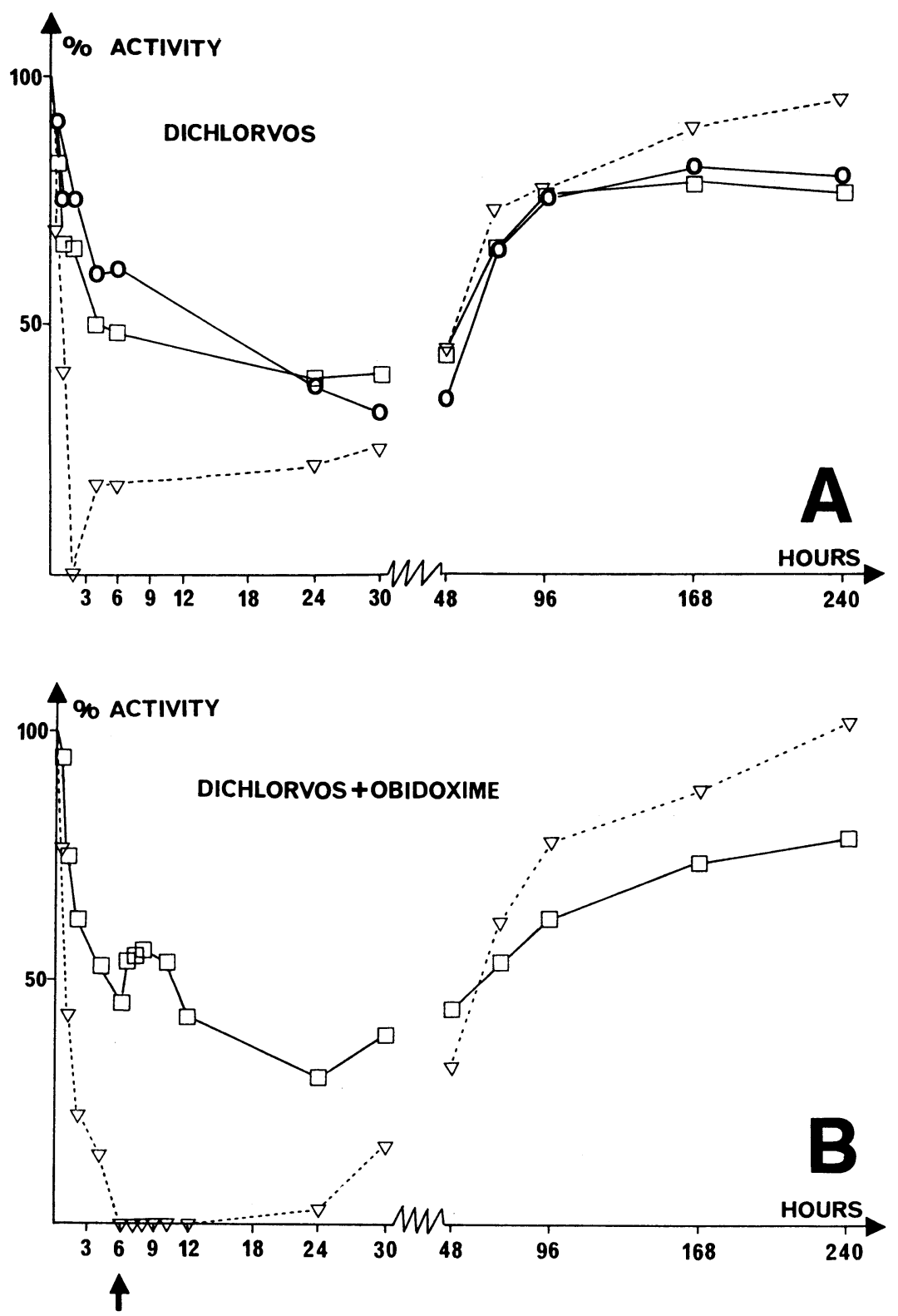

Figu re 3A \& B. Cholinesterase activity as per cent of control in plasma and whole blood from pigs nos. 4 (A) and 6 (B) both treated with dichlorvos. $(\nabla)$ plasma; $(\square)$ whole blood; (O) whole blood after in vitro reactivation with obidoxime (A). The arrow indicates in vivo treatment with obidoxime (B). 

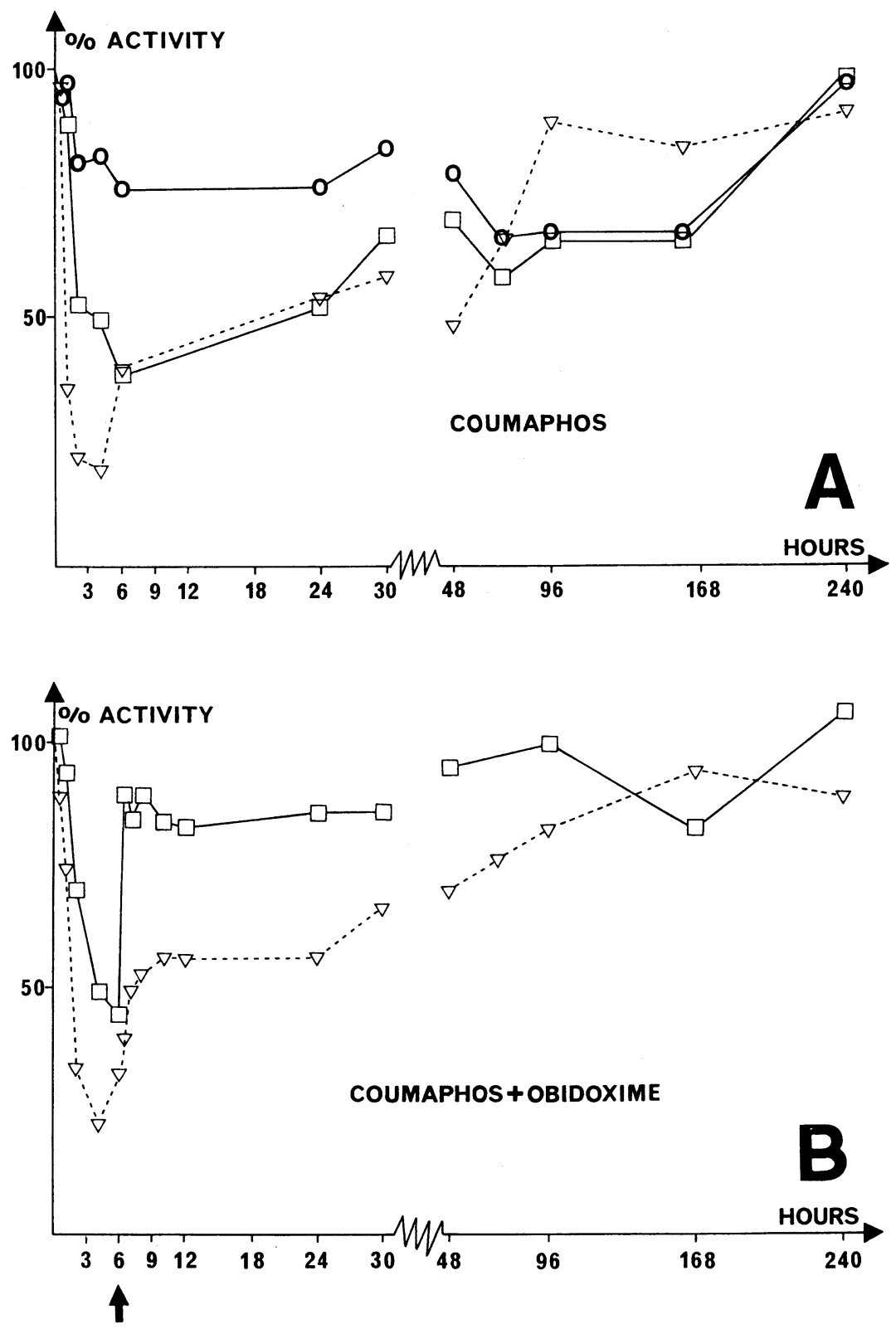

Figur e 4A \& B. Cholinesterase activity as per cent of control in plasma and whole blood from pigs nos. 7 (A) and 9 (B) both treated with coumaphos. ( $\nabla$ ) plasma; ( $\square$ ) whole blood; (O) whole blood after in vitro reactivation with obidoxime (A). The arrow indicates in vivo treatment with obidoxime (B). 
control value, which lasted for the rest of the observation period (Fig. 4B). This pronounced effect is very similar to the effect seen when obidoxime was added to the blood samples (Fig. 4A).

\section{DISCUSSION}

Trichlorfon has previously been shown quickly to inhibit the cholinesterase in whole blood and plasma of pigs treated with 50 or $100 \mathrm{mg}$ per $\mathrm{kg}$ b.wt. orally (Karlog et al. 1971). As in the present study a spontaneous reactivation of the inhibited enzymes began few hours after administration with nearly normal enzyme activities being reached within 10 days.

Dichlorvos as Atgard $\AA$ vet. has been given to pigs by Bossen et al. (1973) and Gyrd-Hansen (1982) who both found - as in the present study - that in this sustained release preparation dichlorvos caused a slowly occurring inhibition of the cholinesterase, the activity of which reached a minimum $30 \mathrm{~h}$ after administration. Spontaneous reactivation in whole blood took place from $48 \mathrm{~h}$ on and $80 \%$ of normal activity was reached in 8-10 days both in the present study and in that of Gyrd-Hansen (1982) while Bossen et al. (1973) found it took somewhat longer to reach this level.

In vitro reactivation of inhibited cholinesterase by means of obidoxime was not possible after treatment with dichlorvos, while after treatment with the chemically closely related trichlorfon, obidoxime was effective for at least $6 \mathrm{~h}$ after administration of the organophosphate. The same observation that obidoxime is able to reactivate trichlorfon-inhibited cholinesterase was made by Zech et al. (1967) in experiments with horse serum. Sanderson \& Edson (1959) observed that the ability of oximes to reactivate depends on the nature of the enzyme-phosphorylating portion of the organophosphates and that reactivation is not possible with certain dimethyl phosphates.

In the present study reactivation was only possible in less than $24 \mathrm{~h}$ after treatment with trichlorfon. This is in agreement with the observations made by Hobbiger (1956) and Davies $\&$ Green (1959) that when enzyme inhibition has lasted for some time reactivation can no longer take place. Other investigators (Sanderson \& Edson 1959, Coult et al. 1966) have found that enzymes inhibited by di-isopropyl and dimethyl phosphates undergo this "ageing" much more readily than when inhibited 
by diethyl phosphates. In accordance with this cholinesterase reactivation could be accomplished for more than $30 \mathrm{~h}$ after treatment with the diethyl phosphate coumaphos.

In the 3 pigs (nos. 3, 6 and 9) treated with obidoxime $6 \mathrm{~h}$ after administration of an organophosphates drug an increase in cholinesterase activity was obtained, which corresponds very well with the enzyme reactivation achieved by adding obidoxime to the blood samples taken from the other pigs $6 \mathrm{~h}$ after these were given the same organophosphate drugs.

If such good correlation between in vivo and in vitro reactivation always exists - and not only $6 \mathrm{~h}$ after exposure - it can be concluded that in case of overdosage or poisoning with one of the 3 organophosphates studied treatment with obidoxime would only be expedient in coumaphos poisonings - and maybe in severe cases of trichlorfon poisoning if the therapy could be administered within a few hours after the accident. Thus while atropin should always be used in the treatment of organophosphate poisoning obidoxime is only beneficial in special cases depending on the organophosphate involved.

\section{REFERENCES}

Augustinsson, K.-B.: Cholinesterases. A study in comparative enzymology. Acta physiol. scand. 1948, 15, suppl. 52.

Bossen, F., O. Karlog \& F. Rasmussen: The cholinesterase activity in red blood cells and plasma after oral intake of Atgard $\AA$ vet. (dichlorvos) in pigs. Nord. Vet.-Med. 1973, 25, 584-587.

Coult, D. B., D. J. Marsh \& G. Read: Dealkylation studies on inhibited acetylcholinesterase. Biochem. J. 1966, 98, 869-873.

Davies, D. R. \& A. L. Green: The kinetics of reactivation, by oximes, of cholinesterase inhibited by organophosphorus compounds. Biochem. J. 1956, 63, 529-535.

Davies, D. R. \& A. L. Green: The chemotherapy of poisoning by organophosphate anticholinesterases. Brit. J. industr. Med. 1959, $16,128-134$.

Gyrd-Hansen, N.: Cholinesterase inhibition by Atgard $\circledast$ vet. (dichlorvos) in single or divided doses. Nord. Vet.-Med. 1982, 34, 49-51.

Heilbronn, E. \& B. Tolagen: Toxogonin in sarin, soman and tabun poisoning. Biochem. Pharmacol. 1965, 14, 73-77.

Hobbiger, F.: Chemical reactivation of phosphorylated human and bovine true cholinesterases. Brit. J. Pharmacol. 1956, 11, 295303.

Hobbiger, F.: Protection against the lethal effects of organophosphates by pyridine-2-aldoxime methiodide. Brit. J. Pharmacol. 1957, 12, $438-446$. 
Karlog, O.: Experimental studies on the effect of P-2-AM in acute poisoning with alkyl phosphates. Nord. Vet.-Med. 1960, 12, 3746.

Karlog, O., F. Rasmussen \& B. Skafte: The cholinesterase activity in red blood cells and plasma after cutaneous or oral application of metrifonatum NFN in pigs. Nord. Vet.-Med. 1971, 23, 170175.

Natoff, I. L. \& B. Reiff: Quantitative studies of the effect of antagonists on the acute toxicity of organophosphates in rats. Brit. J. Pharmacol. 1970, 40, 124-134.

Sanderson, D. M. \& E. F. Edson: Oxime therapy in poisoning by six organophosphorus insecticides in the rat. J. Pharm. Pharmacol. 1959, 11, 721-728.

Wilson, I. B.: Acetylcholinesterase. XI Reversibility of tetraethyl pyrophosphate inhibition. J. biol. Chem. 1951, 190, 111-117.

Wilson, I. B. \& S. Ginsburg: A powerful reactivator of alkylphosphateinhibited acetylcholinesterase. Biochim. Biophys. Acta 1955, 18, 168-170.

Zech, R., W. D. Erdmann \& H. Engelhard: Grenzen der Therapie mit oximen bei vergiftungen mit insekticiden alkylphosphaten. (Limits to the therapy of intoxications by insecticidal alkylphosphates with oximes). Arzneim. Forsch. 1967, 17, 1196-1201.

\section{SAMMENDRAG}

Reaktivering med obidoxim ved alkylfosfat-hæmmet kolinesteraseaktivitet hos grise.

Muligheden for at reaktivere alkylfosfat-hæmmet kolinesteraseaktivitet med obidoxim blev unders $\emptyset$ gt på grise behandlet med enten trichlorfon, dichlorvos eller coumaphos. Kolinesteraseaktiviteten i blodet blev på 6 grise målt både $\mathrm{f} \phi \mathrm{r}$ og efter in vitro reaktivering med obidoxim. Tre grise blev behandlet med obidoxim 6 timer efter indgift af alkylfosfat for at studere muligheden for in vivo reaktivering.

Unders $\emptyset$ gelserne viste tydelig overensstemmelse mellem obidoxim's evne til at reaktivere hæmmet kolinesterase in vitro og in vivo. Samtidig observeredes en klar forskel $i$ muligheden for reaktivering efter behandling med de 3 alkylfosfater. Reaktivering var således ikke mulig efter behandling med dichlorvos, mens hæmmet kolinesterase kunnè reaktiveres i mindst 6 timer efter indgift af trichlorfon. Hos coumaphos-behandlede grise kunne reaktivering med obidoxim opnås i mere end 24 timer.

(Received January 25, 1984).

Reprints may be requested from: N. Gyrd-Hansen, the Department of Pharmacology and Toxicology, Royal Veterinary and Agricultural University, Bülowsvej 13, 1870 Copenhagen, Denmark. 